\title{
Maize Chlorotic Mottle Virus: Distribution, Alternative Hosts, Transmission Mechanisms and Management Options
}

\author{
Bayissa Regassa \\ Ethiopia Institute of Agricultural Research, Ambo Agricultural Research Center, P. O. Box 37, Ambo, Ethiopia
}

\begin{abstract}
Plant virus diseases are serious constraints to the productivity and profitability of a wide range of crops. Epidemics of existing plant virus diseases and the emergence of novel virus diseases have become a serious threat to subsistence and commercial agriculture. The knowledge of virus transmission and its survival helps to understand how the disease transmits from infected plant to healthy, where it reserved, and this will lead to identify the most important variables and focus efforts to develop sustainable management strategies. Maize chlorotic mottle virus (MCMV) is transmitted from location to location, and from plant to plant through various mechanisms (mechanically, seed, insect vectors, and soil) and many wild types of grass and cultivated crops, MCMV infected maize residue are used as its reservoirs. Different weed species and cultivated plants used as alternate hosts, and soil and seed transmissibility of MCMV are epidemiologically important and contribute to maintaining virus inoculum available in the absence of maize in the field and increase the chances of continuing its survival. Integrated disease management approach, regular field monitoring, assessment of virus symptoms, and rouging-out diseased plants are recommended to prevent further spread by insect vectors. Apart from this, because the disease is still widespread in various countries, intensive MCMV recruitment, combined with integrated disease management, requires ongoing practice in countries where MCMV is prevalent and in those countries that have not yet reported MCMV.
\end{abstract}

Keywords: Integrated management; Insect vector; plant residue; Soil transmission; Zea mays

DOI: $10.7176 / \mathrm{JBAH} / 11-19-04$

Publication date:October $31^{\text {st }} 2021$

\section{Introduction}

Maize (Zea mays L.) is the main staple food in Latin America and Sub-Saharan Africa (Iken and Amusa, 2004). The crop is ranked the third most important cereal plant after wheat and rice (Khalili et al., 2013). Presently maize is cultivated throughout the year in almost every part of the world. The potential yield of maize per unit land area is highly dependent upon fertility levels, plant population, management practices, and the inherent potential of the variety adapted to that area.

Plant viruses are among the major factors that affecting food production worldwide and cause vast economic losses. It results in the loss by limiting plant produce quality and quantity (Thresh, 2006; Van der Vlugt, 2006) and have an estimated economic impact of more than $\$ 30$ billion per year (Sastry and Zitter, 2014). Globally, there are more than 32 maize infecting viruses recorded on maize. Among them, Maize chlorotic mottle virus (MCMV) is one of the most devastating maize productions worldwide. Hence the objective of this paper is to overview the MCMV global distribution, host range, transmission mechanism, and its management options.

\section{Maize chlorotic mottle virus (MCMV) and its strains}

MCMV is the only identified member of the genus Machlomovirus in the family Tombusviridae (King et al., 2011). There are several strains of MCMV have been identified. MCMV-NE is the isolate from Nebraska (Stenger and French, 2008), MCMV-K and MCMV-P are isolated from Kansas and Peru, respectively (Uyemoto, 1983) while MCMV-YN the Chinese isolate from Yunnan (Xie et al., 2011). The US isolates (K and NE) share 99.5\% Nucleotide sequence identity, a clear indication the two isolates are related (Nutter et al., 1989' Stenger and French, 2008). MCMV isolates from Thailand were closely related to China strains with 98-99.6\% sequence similarity (Wu et al., 2013). The nucleotide sequence similarity of MCMV isolates from East African countries is $99 \%$ (Mahuku et al., 2015), that the whole region has similar MCMV viruses interacting mainly with SCMV. Kenyan isolates had 95-98\% sequence similarity (Wangai., et al., 2012). Ethiopia isolate was similar to East Africa isolate with 99\% similarity (Mahuku et al., 2015). Rwanda, Kenya, China isolates were identical with 99\% and 96-97\% with USA isolates (Adams et al., 2014).

\subsection{Yield loses caused by MCMV}

MCMV infects maize plants and causes significant losses in maize production. Under natural field conditions, MCMV causes 10-15\% crop loss and up to 59\% loss under inoculated conditions (Castillo and Loayza, 1977). When MCMV co infects maize plants with other maize viruses from the family Potyviridae, such as maize dwarf mosaic virus (MDMV) (genus: Potyvirus), Sugar cane mosaic virus (SCMV) (genus: Potyvirus), or Wheat streak 
mosaic virus (WSMV) (genus: Tritimovirus), their synergistic effect causes a more severe disease called Maize lethal necrosis (MLN), previously known as Corn Lethal Necrosis which leads to almost $100 \%$ field loss (Uyemoto et al. 1980; Goldberg and Brakke, 1987; Xie et al., 2011). When MCMV co-infects maize with any potyvirus infecting maize plants, a synergistic interaction occurs, causing a severe disease (Fig. 1) and yield losses. MCMV can cause 91\% yield loss occurs in co-infection with either MDMV or Wheat streak mosaic virus (WSMV) (Niblett and Claflin, 1978). In Africa, MCMV is a serious disease of maize from its first outbreak in Kenya (Wangai et al., 2012) to the present (Regassa et al., 2020; 2021). In Africa 30-100\% loss in co-infection with SCMV (Wangai et al., 2012, Mahuku et al., 2015; Guide et al., 2018; Regassa et al., 2020).

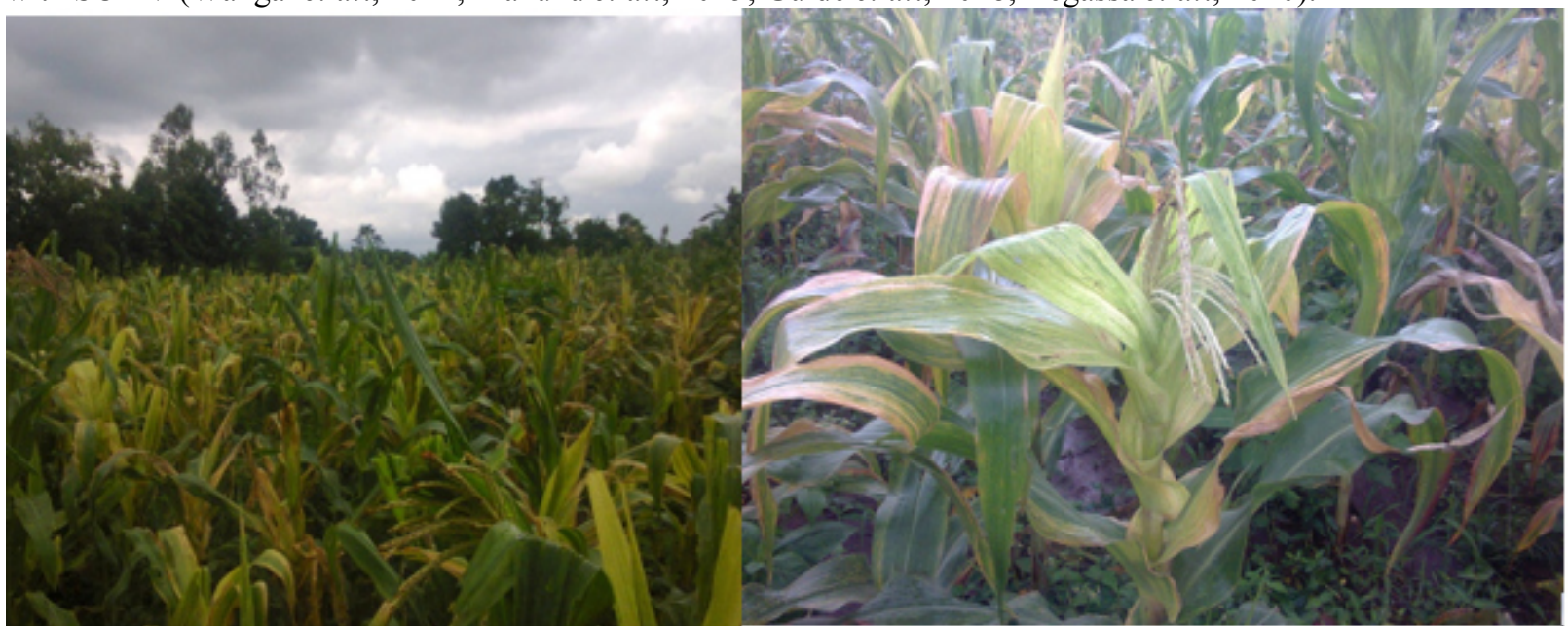

Fig. 1. MCMV co-infection with SCMV causing severe damage on maize under natural field condition

\subsection{MCMV symptoms}

Depending on the host genotype, MCMV infection symptoms range from mild to severe chlorotic mottle, leaf necrosis, stunted growth, a shortened male inflorescence with few spikes, malformed or partially filled ears, and premature death of plants (Niblett and Claflin, 1978; Uyemoto et al., 1981; Regassa et al., 2021).

When MCMV co-infects maize with a potyvirus infecting maize, the infected maize plants under field condition show a various range of symptoms, such as chlorotic mottling of the leaves (Fig 2 a and b), typically starting from the base of the young leaves in the whorl and extending upwards toward the leaf tips. The leaves can experience necrosis at the leaf margins that progress to the mid-rib resulting in drying of the whole leaf (Fig $2 \mathrm{~d}$ ). Other symptoms include premature aging of the plants and mild to severe leaf mottling. Severely affected plants form small cobs with little or no grain set (Fig $2 \mathrm{f}$ and g). The entire crop can frequently be killed before tasseling (Niblett and Claflin, 1978; Uyemoto et al., 1980, 1981; Wangai et al., 2012; Regassa et al., 2021).
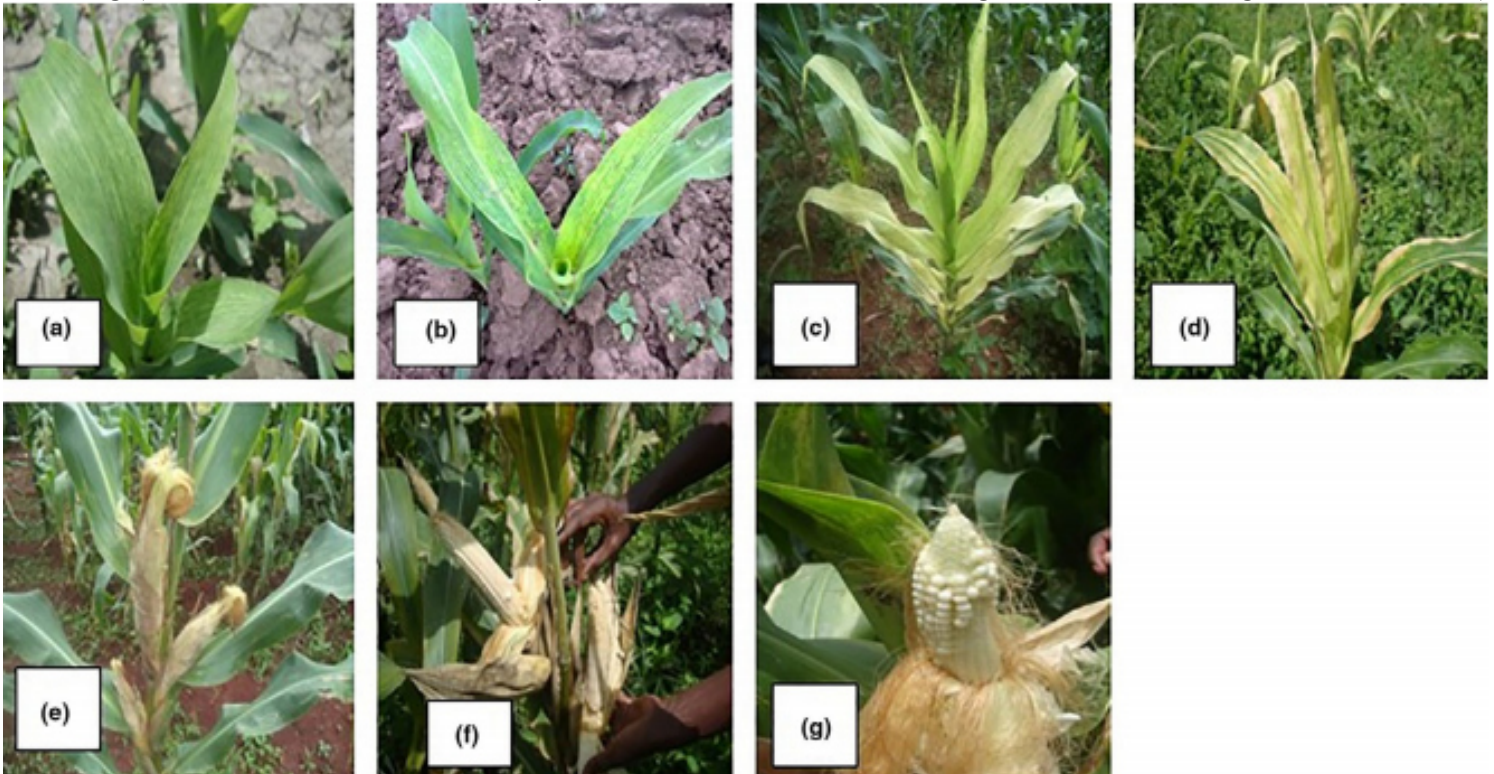

Fig 2. MCMV co-infection with SCMV and symptoms commonly observed under natural field condition: (a) chlorotic, (b and c) mild to severe leaf mottling, (d) necrosis of leaf margins, (e) drying cob, (f and g) poor or no grain filling. Source: Regassa et al. (2021). 


\subsection{History and Global distribution of MCMV}

MCMV was first described in maize from Peru in 1973 and reported in 1974 (Castillo and Hebert, 1974) and thereafter was reported on maize plants in different countries of South America, North America, Europe, Asia and Africa. In Africa, MCMV was first occurred in Kenya in 2011 and reported in 202 (Wangai et al., 2012), since then have been reported and widespread in other East African countries. The following Table (Table 1) provides the year in which samples first tested positive for MCMV in each country it has reported in.

Table 1. MCMV global distribution

\begin{tabular}{|c|c|c|}
\hline Continent/Country & Earliest report & Reference \\
\hline \multicolumn{3}{|l|}{ SOUTH AMERICA } \\
\hline Peru & 1973 & Castillo and Hebert (1974) \\
\hline Argentina & 1982 & Teyssandier and Bo (1983) \\
\hline Ecuador & 2015 & Quito-Avila et al. (2016) \\
\hline \multicolumn{3}{|l|}{ NORTH AMERICA } \\
\hline USA & 1976 & Niblett and Claflin (1978) \\
\hline Mexico & 1984 & Gordon et al. (1983) \\
\hline Hawaii & 1990 & Jiang et al. (1992) \\
\hline Kansas & 1977 & Nault et al. (1978) \\
\hline Nebraska & 1981 & Doupnik et al. (1982) \\
\hline Texas & 1978 & Kessler (1979) \\
\hline \multicolumn{3}{|l|}{ EUROPE } \\
\hline Spain & 2015 & Achon et al. (2017) \\
\hline \multicolumn{3}{|l|}{ ASIA } \\
\hline Thailand & 1982 & Klinkong and Sutabutra (1983) \\
\hline China & 2011 & Xie et al. (2011) \\
\hline Yunnan & & Wang et al. (2014) \\
\hline Taiwan & 2014 & Deng et al. (2014) \\
\hline \multicolumn{3}{|l|}{ AFRICA } \\
\hline Kenya & 2011 & Wangai et al. (2012) \\
\hline Tanzania & 2012 & Mahuku et al. $2015 \mathrm{~b}$ \\
\hline Uganda & 2013 & Mahuku et al. $2015 \mathrm{~b}$ \\
\hline Rwanda & 2013 & Adams et al. (2014) \\
\hline Democratic Republic of Congo & 2013 & Lukanda et al. (2014) \\
\hline Ethiopia & 2014 & Mahuku et al. (2015a) \\
\hline South Sudan & 2014 & Mahuku et al. $2015 b$ \\
\hline
\end{tabular}

\subsection{MCMV host range}

\subsubsection{Natural alternative hosts}

Earlier, maize was reported as the only known natural hosts of MCMV (Scheets, 2004), recent studies, however, have identified MCMV from sugarcane; finger millet, sorghum, Napier grass and Kikuyu grass (Wang et al., 2014; Kusia et al. 2015; Mahuku et al., 2015; Regassa et al., 2021). Our recent study (Regassa et al., 2021) showed that the Poaceae family had the highest number of grass species that were alternate hosts for MCMV, and Cyperus cyperoids and Cyperus cyperoides from the Cyperaceae family were naturally infected by MCMV (Regassa et al., 2021). Most of the natural alternative hosts identified were annual and perennial grasses in nature (Table 2), and common in the maize growing areas.

Table 2. Natural alternate hosts of MCMV identified

\begin{tabular}{llll}
\hline Family & Species & Life cycle & Type \\
\hline Cyperaceae & Cyperus rotundus L. & Perennial & Sedges \\
Cyperaceae & Cyperus cyperoides L. & Perennial & Sedges \\
Poaceae & Snowdenia polystachya (Fresen.) plig. & Annual & Grasses \\
Poaceae & Cynodon nlemfuensis Vanderyst. & Perennial & Grasses \\
Poaceae & Digitaria sanguinalis (L.) Scop. & Annual & Grasses \\
Poaceae & Echinochloa colona L. & Annual & Grasses \\
Poaceae & Oplismenus hirtellus L. & Perennial & Grasses \\
Poaceae & Pennisetum purpureum Schumach. & Perennial & Grasses \\
Poaceae & Phalaris paradoxa L. & Annual & Grasses \\
Poaceae & Sorghum bicolor L. & Annual & Grasses \\
Poaceae & Saccharum officinarum L. & Perennial & Grasses \\
\hline
\end{tabular}

Source: Regassa et al. (2021) 
Different types of MCMV symptoms were observed on different plant species of its alternative hosts. The symptoms observed included mosaics, mottling, yellowing, necrosis that develop from leaf margins to the midrib, and purple discoloration of leaves. For instance, MCMV symptoms on Cyperus cyperoids and Snowdenia polystachya were expressed as yellowing, while it showed mosaic and chlorotic symptoms on Oplismenus hirtellus (Fig.2) (Regassa et al., 2021).

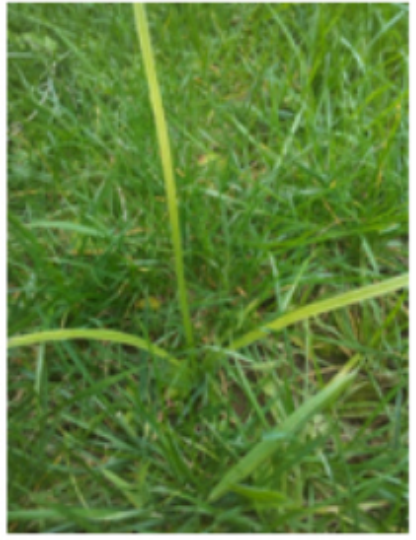

Cyperus cyperoids

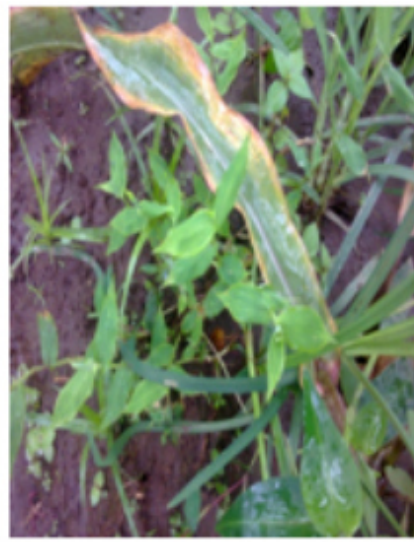

Oplismenus hirtellus

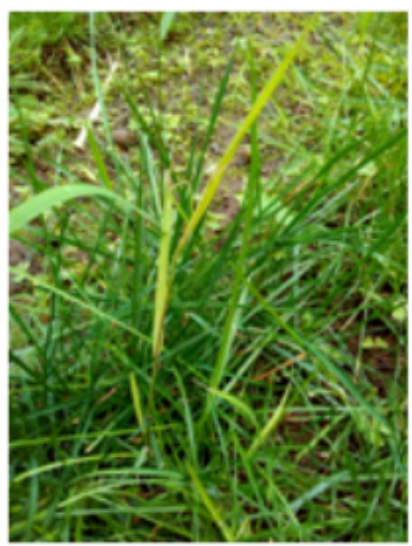

Snowdenia polystacya

Fig. 3. Maize chlorotic mottle virus (MCMV) on naturally infected different alternate hosts shows yellowing and mosaic symptoms.

\subsubsection{Experimental host range}

Bockelman et al. (1982) has identified a broad range of MCMV experimental host range that includes at least 19 grass species, but it does not infect dicots. According to Sheets (2004), 73 grass species in 35 genera have been tested for susceptibility to virus strains MCMV-Kansas, MCMV-Peru, or both (Table 3).

Table 3. Plants tested for susceptibility to strains of MCMV (Scheets, 2004)

\begin{tabular}{lll}
\hline Immune genera & Susceptible genera & Genera with both immune and susceptible species \\
\hline Axoponus Chloris & Andropogon & Agropyron \\
Elymus & Avena & Bromus \\
Festuca & Bouteloua & Cenchrus \\
Lolium & Buchloe & Cynodon \\
Oryza & Calamovilfa & Dactylis \\
Paspalum & Eleusine & Digitaria \\
Poa & Eragrostris Euchlaena & Echinochloa \\
Saccharum & Hordeum & Panicum \\
& Secale & Phalaris \\
& Sorgastrum & Setaria \\
& Sorghum Spartina & Zea \\
& Tripsacum Triticum & \\
\hline
\end{tabular}

Our recent MCMV experimental host range study (Regassa et al., 2021) revealed that among the 39 weed species tested for reaction to MCMV using artificial inoculation in the greenhouse, 20 species were susceptible to MCMV infection (Table 4). Cereal crops (barley and wheat) were also experimentally infected by MCMV (Fig 3, G and $\mathrm{H}$ ). 

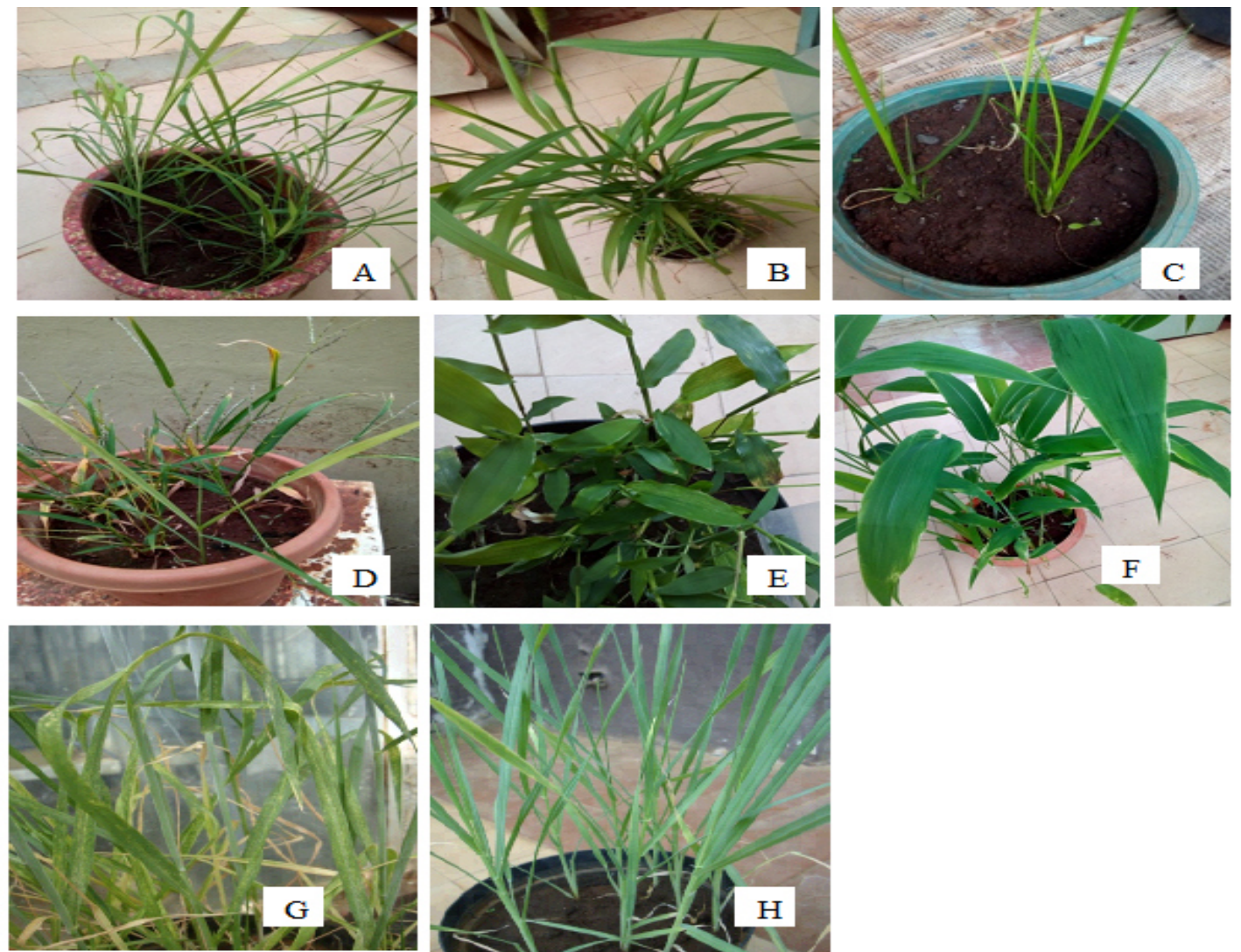

Fig 4. Maize chlorotic mottle virus (MCMV) symptoms (mild chlorotic, yellowing, necrosis starting from leaf merges to mid-rib) on mechanically inoculated grass weeds and cereal crops $(A=$ dinebra retroflexa, $\mathbf{B}=$ Setaria verticillata, $\mathbf{C}=$ Cyperus assimilis, $\mathbf{D}=$ Digitaria ternta, $\mathbf{E}=$ Oplismenus hirtellus, $\mathbf{F}=$ Sorghum arundianaceum, $\mathbf{G}=$ wheat, $\mathbf{H}=$ barley.

Table 4. MCMV experimental host (Weed species) identified by artificially inoculation in greenhouse

\begin{tabular}{|c|c|c|c|}
\hline Family name & Species name & Life cycle & Type of weed \\
\hline Cyperaceae & Cyperus assimilis Steud. & Annual & sedges \\
\hline Cyperaceae & Cyperus esculentus L. & perennial & sedges \\
\hline Cyperaceae & Cyperus rotundus $\mathrm{L}$. & Perennial & Sedges \\
\hline Poacceae & Cenchurus ciliaris L. & perennial & Grasses \\
\hline Poacceae & Cyndon nlemfuencis Vanderyst. & Perennial & Grasses \\
\hline Poaceae & Andropogon abyssinicus (Fresen.) R. Br. & Annual & Grasses \\
\hline Poaceae & Cyndon dactylon (L.) Pers. & Perennial & Grasses \\
\hline Poaceae & Denebra retroflexa (Vahl.) panzer & Annual & Grasses \\
\hline Poaceae & Digitaria abyssinica (A. Rich) Stapf & Perennial & Grasses \\
\hline Poaceae & Digitaria ischaemum (Schreb.) muhl. & Annual & Grasses \\
\hline Poaceae & Digitaria ternate (A. Rich.) Stapf & Annual & Grasses \\
\hline Poaceae & Echinocloa colona (L.) Link & Annual & Grasses \\
\hline Poaceae & Eleusine indica L. Gaertn. & Annual & Grasses \\
\hline Poaceae & Eragrostis cilianesis (All.) Lut. & Annual & Grasses \\
\hline Poaceae & Pennisetum ramosum (Hochst.) Schweinf. & Annual & Grasses \\
\hline Poaceae & Phalaris paradoxa L. & Annual & Grasses \\
\hline Poaceae & Setaria pumila (poir.) Roem. \& schult.) & Annual & Grasses \\
\hline Poaceae & Setaria verticillata (L.) P.Beauv. & Annual & Grasses \\
\hline Poaceae & Snowdenia polystachya (Fresen.) pilg & Annual & Grasses \\
\hline Poaceae & Sorghum arundinaceum (Desv.) Stapf & Annual & Grasses \\
\hline
\end{tabular}

Source: Regassa et al. (2021)

\subsection{Mechanisms of MCMV transmission}

2.5.1. Mechanical Transmission

MCMV is transmitted mechanically by sap. Mechanical transmission occurs when a plant comes in contact with other plants and leaves rub together or by humans' interferences like tools/hands/clothing. It involves the 
introduction of an infective virus or biologically active virus into a suitable site in the living cells through wounds or abrasions in the plant surface. Spreading viruses by the mechanical method is generally used for experimental purposes under laboratory/greenhouse conditions.

\subsubsection{Insect vectors}

The transmissions of viruses from plant to plant by vectors provide the main method of spread in the field for many viruses including MCMV that cause severe economic loss (Hull, 2014). In Ethiopia, studies on the MLN (MCMV is the main component) distribution and factors associated with its epidemic show that the spread of MLN causing viruses (MCMV and SCMV) are linked to the free movement of insect vector and continuous availability of the host plants (Regassa et al., 2020). In the United States mainland, MCMV has been reported to be transmitted by six different species of chrysomelid beetles, including the cereal leaf beetle (Oulema melanopa), corn flea beetle (Chaetocnema pulicaria), flea beetle (Systena frontalis), southern corn rootworm (Diabrotica undecimpunctata), western corn rootworm (Diabrotica virgifera) and northern corn rootworm (Diabrotica longicornis) (Jiang et al., 1992; Nault et al., 1978).

The other vector that transmits MCMV is maize/ corn thrips, Frankliniella williamsi Hood (Thysanoptera: Thripidae) has been identified to be the main vector (Cabanas et al., 2013) in Hawai, USA. Maize thrips transmit MCMV in a non-persistent manner. Both larvae and adults of corn thrips transmitted MCMV for up to 6 days after acquisition, with decreasing rates of transmission as time progressed.

\subsubsection{Seed Transmission}

MCMV is also transmitted by seed. The rate of MCMV seed transmission observed by Jensen et al. (1991) who evaluated 42,000 seedlings and found a $0.04 \%$ transmission rate in Hawaii, USA. In line with this finding Quito-Avila et al. (2016) from Ecuador reported 8 and 12\% seed transmission of MCMV. Zhang et al. (2011) reported MCMV seed transmission of 2 seeds in $600(0.33 \%)$ in Chinese maize. Our recent MCMV seed transmission study result (Regassa et al., 2021) showed the mean seed to the seedling transmission rate of MCMV was $0.073 \%$ with a range of 0 to $0.17 \%$ among 20 different maize varieties studied. Fourteen maize genotypes had some levels of seed transmission $(0.03 \%-0.017 \%)$ for MCMV. Seed transmission rates of the viruses were influenced by the seed lot and maize varieties used.

\subsubsection{Transmission through soil and plant residue}

Transmission in soil water or crop residues has been suggested for MCMV, and there are a number of reports of increased disease pressure after heavy rainfall and in soils with a higher water capacity (Jensen, 1991; Uyemoto, 1983). Mahuku et al. (2015) found that planting clean seeds in the soil from MLN-affected areas resulted in $69 \%$ MCMV infection. Our current study also confirmed that low soil transmission (4.24-13.5\%) MCMV can be transmitted from infested soil to newly raised maize seedlings and it also reserved in maize residues (Regassa et al., unpublished data). Similar findings were previously reported on MCMV transmission through soil (Nyvall, 1999). It also reported that MCMV can be transmitted through infected plant residues that play important roles in the survival of the virus especially when maize is planted during the off-season (Uyemto, 1983; Montenegro and Castillo, 1996).

\subsection{Management of MCMV}

Plant virus diseases including MCMV are intrinsically difficult to manage directly by measures such as direct use of chemical pesticides, an integrated management options which include the use of disease-resistant crop varieties, the uses of cultural practices like crop sanitation and removal of infection sources, use of virus-free seeds and chemical pesticides such as seed treatment and foliar spray to indirectly control vector insects is the most feasible option.

The most effective control for MCMV has been achieved through the integration of cultural practices with insecticides and host resistance (Nelson et al., 2011). Alternatively, crop rotation with non-maize crops has been shown to reduce the incidence of MCMV the following year (Phillips et al., 1982; Uyemoto, 1983). Maize Producers are advised to practice crop rotation for at least two seasons with alternative non-cereal crops such as potatoes, sweet potatoes, cassava, beans, bulb onions, spring onions, vegetables and garlic. Planting different crops each season will diversify farm enterprises. Manure and basal/top dressing fertilizers can be applied to boost plant vigor.

It is necessary to use good field sanitation methods, including weed control measures to eliminate alternate hosts for potential vectors (Wangai et al., 2012; Regassa et al., 2020, 2021). Infected foliar material should be removed from the field to reduce pathogen and vector populations. In Hawaii, USA producers of maize seed spray regularly after planting to control insects that spread the virus (Nelson et al., 2011). The use of tolerant or resistant varieties ultimately would be the most effective means of managing MCMV (Regassa et al., 2020). Superior resistance to MCMV is widely available in tropical maize seed stocks and provides the best control for this disease. The use of host resistance is the most desirable and feasible method in virus disease management. According to Nelson et al. (2011), trials performed in Hawaii in 2011 found many tropical inbred lines and varieties to be highly resistant to MCMV. Almost all temperate climate inbred lines and hybrids are highly 
susceptible to the virus (Nelson et al., 2011).

MCMV infested soil and infected maize residue play an important role in the survival, inoculum source and spread of MCMV. Thus, proper management of crop residues in the field after harvest is necessary to minimize the adverse effects of MCMV on maize production. Crop rotation is one of the ways of freeing the soil from MCMV disease. Therefore, as part of integrated management of MCMV, maize growers should remove all infected maize materials/residues from the field, ignore any activity that moves the soil from MCMV infected fields or infected maize residue from one place to another.

\section{Conclusions and Recommendation}

Because of the level of damage caused and potential of the disease to spread and cause tremendous losses in most major growing areas of the East African countries, MCMV which is the main component of MLN is currently considered as a high-risk emerging disease and given a top priority for intervention by research and crop pest regulatory authorities in the agricultural sector.

Plant virus disease management including MCMV has to be knowledge-based, and thus, it is important to know the geographical distribution and to understand the role of infected seed, alternate hosts, and insect vectors in the emergence and development of disease epidemics. MCMV transmitted from location to location, and from plant to plant through various mechanisms and many kinds of wild grasses and cultivated crops used as its reservoirs. MCMV infected seed, weed and cultivated plants are known as alternate hosts of MCMV are epidemiologically important and maintain the virus inoculum in the absence of maize crop in the field, and support the survival of the virus for continuous infection. Farmers and stakeholders involved in maize cultivation should take preventive measures by eliminating alternate host plants within and in the surrounding areas of maize fields, use virus-free and certified seed from known sources for sowing.

Different weed species and cultivated plants used as alternate hosts, and seed transmissibility of MCMV are epidemiologically important and contribute to maintaining virus inoculum available in the absence of maize in the field and increase the chances of continuing its survival. Therefore, regular field monitoring, assessment of virus symptoms, and rouging-out diseased plants are recommended to prevent further spread by insect vectors. Apart from this, because the disease is still widespread in various countries, intensive MCMV recruitment, combined with integrated disease management, requires ongoing practice in countries where MCMV is prevalent and in those countries that have not yet reported MCMV.

\section{References}

Achon, M.A., Serrano, L., Clemente-Orta, G., Sossai, S. (2017). First report of Maize chlorotic mottle virus on a perennial host, Sorghum halepense, and maize in Spain. Plant Dis. 101, 393.

Adams, I. P., Harju, V. A., Hodges, T., Hany, U., Skelton, A., Rai, S., Deka, M. K., Smith, J., Fox, A., Uzayisenga, B., Ngaboyisonga, C., Uwumukiza, B., Rutikanga, A., Rutherford, M., Ricthis, B., Phiri, N., \& Boonham, N. (2014). First report of maize lethal necrosis disease in Rwanda. New Disease Reports, 29, 22. https://doi. org/10.5197/j.2044-0588.2014.029.022

Bockelman, D. L., Claflin, L. E., Uyemoto, J. K. (1982). Host range and seed-transmission studies of maize chlorotic mottle virus in grasses and corn. Plant Disease, 66(3):216-218

Cabanas, D., Watanabe, S., Higashi, C. H. V., and Bressan, A. (2013). Dissecting the mode maize chlorotic mottle virus transmission (Tombusviridae, Machlomovirus) by Frankiniella williamsi (Thysanoptera: Thripidae). J Econ. Entomology, 106:16-24.

Castillo, J, Hebert, T. T. (1974). New virus disease affecting maize in Peru. (Nueva enfermedad virosa afectando al maiz en el Peru.) Fitopatologia, 9:79-84.

Castillo-Loayza J. (1977). Maize virus and virus-like diseases in Peru. In Proceedings of the International Maize Virus Disease Colloquium and Workshop, ed. LE Williams, DT Gordon, LR Nault, pp. 40-44. Wooster, OH: Ohio Agric. Res. Dev. Cent.

Deng, T. C., Chou, C. M., Chen, C. T, Tsai, C. H., Lin, F. C. (2014). First report of maize chlorotic mottle virus on sweet corn in Taiwan. Plant Dis. 98:1748

Doupnik, B. Jr., Lane, L., Wysong, D. S. (1982). Occurrence, spread, and evaluations of dent corn hybrids and inbred lines for reaction to corn lethal necrosis in Nebraska. In: Phytopathology, 72 (7) 939.

Goldberg, K. B., and M. K. Brakke. (1987). Concentration of Maize chlorotic mottle virus increased in mixed infections with Maize dwarf mosaic virus, strain-B. Phytopathology 77: 162-167.

Gordon, D., Knoke, J., Nault, L., and Ritter, R. (1983). International maize virus disease colloquium and workshop; wooster, ohio; 2-6 aug 1982. proceedings. eds. Technical report.

Guadie, D., Tesfaye, K., Knierim, D., Winter, S., \& Abraham, A. (2018). Survey and geographical distribution of maize viruses in Ethiopia. European Journal of Plant Pathology, 153, 271-281.

Hull, R. (2014). Assay, Detection, and Diagnosis of Plant Viruses. Plant Virology, 755-808. doi:10.1016/b978$0-12-384871-0.00013-3$ 
Iken, J. E., Amusa, N. A. (2004). Maize research and productivity in Nigeria. African Journal of Biotechnology, 3(6),302-307.

Jensen, S. G., Wysong, D. S., Ball, E. M., Higley, P. M. (1991). Seed transmission of maize chlorotic mottle virus. Plant Dis. 75:497-498.

Jiang, X. Q., Meinke, L. J., Wright, R. J., Wilkinson, D. R., Campbell, J. E. (1992). Maize Chlorotic Mottle Virus in Hawaiian-grown maize: Vector relations, host range and associated viruses. Crop Protection, 11(3), 248-254. https://doi.org/10.1016/0261-2194(92)90045-7

Khalili, M., Naghavi, M. R., Aboughadareh, A. P., Rad. H. N. (2013). Effects of Drought Stress on Yield and Yield Components in Maize cultivars (Zea mays L.), International Journal of Agronomy and Plant Production, 4(4), 809-812.

King, A.B.S., and Saunders, J. L. (1984). The invertebrate pests of annual food crops in Central America: a guide to their recognition and control. Overseas Development Administration, London.

Klinkong, T., Sutabutra, T. (1982). A new virus disease of maize in Thailand. In: Proceedings of the International Maize Virus Disease Colloquium and Workshop (eds. Gordon, D.T., Knoke, J.K., Nault, L.R., Ritter, R.M), Ohio Agric. Res. Dev. Cent., Wooster, OH, pp. 191-193.

Kusia, E. S., Subramanian S., Nyasani, J. O., Khamis F., Villinger, J., Ateka E., and Pappu H. R. (2015). First report of lethal necrosis disease associated with co-infection of finger millet with Maize chlorotic mottle virus and Sugarcane mosaic virus in Kenya. Plant Disease, doi: http://dx.doi.org/10.1094/PDIS-10-141048-PDN.

Lukanda, M., Owati, A., Ogunsanya, P., Valimunzigha, K., Katsongo, K., Ndemere, H., Kumar, P. L. (2014). First report of Maize Chlorotic Mottle Virus infecting maize in the Democratic Republic of the Congo. Plant Dis. 98(10):1448-1449.

Mahuku, G., Lockhart, B. E., Wanjala, B., Jones, M.W., Kimunye, J.N., Stewart, L.R., Cassone, B.J., Sevgan, S., Nyasani, J. O., Kusia, E., Kumar, P. L., Niblett, C. L., Kiggundu, A., Asea, G., Pappu, H. R., Wangai, A., Prasanna, B. M., Redinbaugh, M. G. (2015b). Maize Lethal Necrosis (MLN), an emerging threat to maizebased food security in sub-Saharan Africa. Phytopathology 105, 956-965.

Mahuku, G., Wangai, A., Sadessa, K., Teklewold, A., Wegary, D., Ayalneh, D., Adams, I., Smith, J., Bottomley, E., Bryce, S., Braidwood, L., Feyissa, B., Regassa, B., Wanjala, B., Kimunye, J. N., Mugambi, C., Monjero, K., \& Prasanna, B. M. (2015). First report of Maize chlorotic mottle virus and maize lethal necrosis on maize in Ethiopia. Plant Disease, 99(12), 1870.

Montenegro, M. T., Castillo, L. J. (1996). Survival of maize chlorotic mottle virus (MCMV) in crop residues and seeds. Fitopatologi, 31(2):1 07-113.

Nault, L. R., Styer, W. E., Coffey, M. E., Gordon, D. T., Negi, L. S., Niblett, C. L. (1978). Transmission of maize chlorotic mottle virus by chrysomelid beetles. Phytopathology, 68(7):1071-1074

Nelson, S., Brewbaker, J., Hu, J. (2011). Maize Chlorotic Mottle Virus. Plant Disease, 79:1-6.

Niblett, C. L., Claflin, L. E. (1978). Corn lethal necrosis - a new virus disease of corn in Kansas. Plant Disease Reporter, 62(1):15-19

Nutter, R. C., K. Scheets, L. C. Panganiban, and S. A. Lommel. (1989). The complete nucleotide-sequence of the Maize chlorotic mottle virus genome. Nucleic Acids Res. 17: 3163-3177.

Nyvall, R. F. (1999). Field crop diseases, 3rd ed. Iowa State University Press, Ames, IA.

Phillips, N. J., Uyemoto, J. K., Wilson, D. L. (1982). Maize chlorotic mottle virus and crop rotation: effect of sorghum on virus incidence. Plant Dis. 66:376-79

Quito-Avila, D. F., Alvarez, R. A., \& Mendoza, A. A. (2016). Occurrence of maize lethal necrosis in Ecuador: A disease without boundaries? European Journal of Plant Pathology, 146, 705-710.

Regassa B, Abraham A, Fininsa C, Wegary D. (2021). Alternate hosts and seed transmission of maize lethal necrosis in Ethiopia. J Phytopathol. https://doi.org/10.1111/jph.12986

Regassa, B., Abraham, A., Fininsa, C., Wegary, D., \& Wolde-Hawariat, Y. (2020). Distribution of maize lethal necrosis epidemics and its association with cropping systems and cultural practices in Ethiopia. Crop Protection, 134, 105151. https://doi.org/10.1016/j. cropro.2020.105151

Scheets, K. (2004). Maize chlorotic mottle. In: H. Lapierre and P.-A. Signoret (eds.) Viruses and virus diseases of Poaceae (Gramineae). Institut National de la Recherche Agronomique, Paris.

Snipes, K. (2014). Kenya Maize Lethal Necrosis - The growing challenge in Eastern Africa. (September 2011).

Stenger, D. C. and French, R. (2008). Complete nucleotide sequence of a maize chlorotic mottle virus isolates from Nebraska. Archives of Virology, 153(5):995-997.

Teyssandier, E.E., and Bo, S. F. N. (1983). Maize virus diseases in Argentina. In Proceedings International Maize Virus Disease Colloquium and Workshop, pages 87-92.

Thresh, J. M. (2006). Crop viruses and virus diseases: A global prospective. Pages 9-32 in: Virus Diseases and Crop Biosecurity, J. I. Cooper, T. Kuhne and V. P. Polischuk, eds. Springer.

Uyemoto, J. K., Claflin, L. E., Wilson, D. L., Raney, R. J. (1981). Maize chlorotic mottle and maize dwarf 
mosaic viruses; effect of single and double inoculations on symptomatology and yield. Plant Disease, 65(1):39-41

Uyemoto, J. K. (1983). Biology and control of maize chlorotic mottle virus. Plant Disease 67:7 10.

Uyemoto, J. K., Bockelman, D. L., Claflin, L. E. (1980). Severe outbreak of corn lethal necrosis disease in Kansas. Plant Dis. 64: 99-100.

Van der Vlugt, R. A. A. (2006). Plant viruses in European agriculture: Current problems and future aspects. Pages 33-44 in: Virus diseases and crop biosecurity, I. Cooper, T. Kuhne and V. Polischuk, eds. Springer, Dordrecht, The Netherlands. 148 p.

Wang, Q., Zhou, X. P., Wu, J. X. (2014). First report of Maize chlorotic mottle virus infecting sugarcane (Saccharum officinarum). Plant Disease. 98 (4), 572-573. http://apsjournals.apsnet.org/loi/pdis DOI:10.1094/PDIS-07-13-0727-PDN

Wangai, A.W., Redinbaugh, M. G., Kinyua, Z. M., Miano, D. W., Leley, P. K., Kasina, M., Mahuku, G., Scheets, K., Jeffers, D. (2012). First report of maize chlorotic mottle virus and maize lethal necrosis in Kenya. Plant Dis. $96,1582-1582$.

Xie, L., Zhang, J. Z., Wang, Q. A., Meng, C. M., Hong, J. A., Zhou, X. P. (2011). Characterization of Maize chlorotic mottle virus associated with maize lethal necrosis disease in China. J. Phytopathol. 159: 191-193.

Zhang, Y. J., Zhao, W. J., Li, M. F., Chen, H. J., Zhu, S. F., \& Fan, Z. F. (2011). Real-time TaqManRT-PCR for detection of maize chlorotic mottle virus in maize seeds. Journal of Virological Methods, 171, $292-294$. https://doi.org/10.1016/j.jviromet.2010.11.002 